\title{
STUDIES ON THE EPIPHALLUS AND SPERMATHECA IN SOME SPECIES OF THE GENUS ACROTYLUS (ACRIDOIDEA: ORTHOPTERA) FROM PAKISTAN
}

\author{
Barkat Ali Bughio'1, Riffat Sultana ${ }^{1}$, Ali Murad Rahoo' ${ }^{2}$, Naheed Baloch ${ }^{1}$, Shamsher Ali ${ }^{1}$ \\ ${ }^{1}$ Department of Zoology, University of Sindh, Jamshoro, Pakistan. \\ ${ }^{2}$ Wheat Research Institute, Sakrand, Sindh, Pakistan.
}

\section{ART I C L E I N F O}

\section{Article history \\ Received: $3^{\text {rd }}$ November, 2018 \\ Revised: $7^{\text {th }}$ February, 2019 \\ Accepted: $11^{\text {th }}$ February, 2019}

\section{Keywords}

Epiphallus

Spermatheca

Taxonomy

Grasshopper

Acridoidea

\section{A B S T R A C T}

\begin{abstract}
The family Acridoidea of the order Orthoptera comprised of insects including grasshoppers, crickets and locusts with paurometabolous type metamorphosis. The present work reports about the studies on the epiphallus and spermatheca in some species of the genus Acrotylus (Acridoidea: Orthoptera) of Pakistan. The species included Acrotylus humbertianus (Saussure), A. insubricus insubricus (Scopoli) A. patruelis (Herrich-Schaffer) A. longipes longipes (Charpentier) and A. longipes subfasciatus. The spermatheca is an organ playing a key role in insect reproduction allowing the storage of spermatozoa and making them available when needed. Moreover, there is information about the genitalia of these grasshoppers. In the present studies, observations were made on the diagnostic characters of epiphallus and spermatheca that have been useful for the purpose of accurate identification. Epiphallus varied in these species i.e. moderately wide bridge, narrow ancorae and bilobate lophi. Similarly, spermatheca was found of varying sizes and shapes. The spermatheca well dilates to form a sac like structure, for storing the spermatozoa which enter during copulation. The characteristics can be used for the accurate identification of Acrotylus species.
\end{abstract}

Corresponding Author: Barkat Ali Bughio

Email: barkatali2009@gmail.com

(C) 2018 EScience Press. All rights reserved.

\section{INTRODUCTION}

Grasshoppers belonging to subfamily Oedipodinae of the family Acrididae have great economic importance in various areas of Pakistan. Grasshopper species of the genus Acrotylus are known pests of orchards in different localities and cause economic losses to agriculture. These grasshoppers are commonly known as band-winged insects and have different colors. They are widely distributed throughout the world (Ahmed, 1980; Baloch, 2000; Bei-Beinko and Mishchenko, 1951; Dirsh, 1975; Kirby, 1914; Ritchie, 1981, 1982; Tokhai, 1997; Uvarov,
1966; Wagan and Solangi, 1990). The grasshoppers of this genus are entirely vegetarian and voracious feeders, majority of them are active during sunshine and can cause heavy damage in cultivated crops when their population may be increased to high levels. In female insects, after mating, spermatozoa are stored in a particular organ called spermatheca. This structure is an ectodermal in origin. It is responsible for storing sperm and retains the fertilization capability from months up to years. The spermatheca is usually designed with tubular spermathecal glands. Many workers have studied the morphology of spermatheca of 
orthopteran insects and some have published histology of spermatheca of orthopteroid insects (Ahmed and Gillott, 1981; Dirsh, 1957; Gupta, 1948; Kevan et al., 1969; Kharibam et al., 1982; Pal and Ghosh, 1982; Qadri, 1940; Slifer, 1939, 1940a, 1940b, 1940c, 1943a, 1943b). Previously some workers also reported that in some orthopteroid insects, spermathecal gland is lacking (Chiang, 2010; Gschwentner and Tadler, 2000). The present paper reports about the studies on the epiphallus and spermatheca in some species of the genus Acrotylus (Acridoidea: Orthoptera) of Pakistan. The characteristics can be used for the accurate identification of Acrotylus species.

\section{MATERIALS AND METHODS}

Adult specimens of Acrotylus humbertianus (Saussure), $A$. insubricus insubricus (Scopoli), A. patruelis (HerrichSchaffer), A. longipes longipes (Charpentier) and $A$. longipes subfasciatus were collected from local areas of Pakistan viz. grasslands, dry vegetations, rangelands, along the roadsides and rocky areas following the method described by Vickery and Kevan (1983). The collection of grasshoppers was made with the help of insect net and the insects were killed by potassium cyanide in standard entomological killing bottles. After relaxing, supra-anal plate of the specimen was raised smoothly with the help of needle, cut laterally and whole phallic complex was taken out. The phallic complex was immersed in 10\% hot potassium hydroxide solution for 5 to 10 hours in order to remove unsclerotized and non chitinous tissues. They were then thoroughly washed in tap water and examined in glycerol on a cavity slide (without a cover glass) using a stereoscopic dissecting binocular microscope. The spermatheca lying just above the vagina was also removed. The dissected sub genital plate and spermatheca were then washed with $10 \%$ potassium hydroxide solution and examined in water and stored as mentioned above. Identification of specimens was carried out under the stereoscopic dissecting binocular microscope. The diagrams were drawn with the help of 'Ocular square Reticule' placed in right eye piece of the stereoscopic dissecting binocular microscope.

\section{RESULTS}

A total of five species of Acrotylus were identified and described as followed

Family: Acrididae Latereille, 1802

Subfamily: Oedipodinae Walker, 1870

Tribe: Acrotylini

\section{i) Acrotylus humbertianus (Saussure)}

Diagnostic characters: Medium size, Body hairy. Antennae filiform, longer than head and pronotum together with 24 segments. Head shorter and little raised than pronotum. Fastigium of vertex concave, angular, with visible lateral carinulae. Fastigial foveolae present, slightly indistinct, frons vertical. Pronotum short but wide and saddle-shaped; strongly tuberculate, constricted in prozona, median carina well marked, lateral carinae irregular and tuberculate. Generally paler brown in color. Antennae dark brownish with white spots at base, tegmina and wings well developed, membrane of tegmina semitransparent, brown opaque at base, rounded at apex. Wings hyaline, colored at base, with or without band. Hind femur slender and yellowish, hind knee rounded. Hind tibia spinose, inner spurs large. Arolium small. Supra-anal plate elongate or curved with obtuse apex.

Morphometry (length in mm): Female: Body 17-22, Antennae 8, Pronotum 4, Tegmina 18-23, hind Femur 10, hind tibia 9-11.

Male: Body 15-18, Antennae 7, Pronotum 3, Tegmina 1720, hind Femur 9, hind tibia 8-9.

Epiphallus: Epiphallus bridge-shaped, bridge wider and curved outwardly, anterior projections well marked diverging upwardly and with obtuse acute apices. Ancorae long not narrower, straight, sharply incurved and with sub acute apices at apex. Lateral plates wide and more elongated, expanded at base. Lophi elongated rectangular, divided into inner lobate part and outer narrow part, posterior projections prominent almost rounded. Besides the lateral plate oval circular sclerites.

Spermatheca: Ovipositor short with curved valves conical and straight, lower valve with angular lateral projection. The spermatheca with pre-apical diverticulum large laterally upwarded with rounded acute apices at apex. Apical diverticulum sac-like, elongated and smoothly rounded at base (Figure 1).

\section{ii) A. insubricus insubricus (Scopoli)}

Diagnostic characters: Body straight and hairy thoroughly. Antennae filiform longer than head and pronotum together; with 23 segments. Head shorter, little forwarded. Fastigium of vertex cylindrical, convex, angular with well marked lateral carinulae. Fastigial foveolae smoothly indistinct, frons vertical. Pronotum short, wide posteriorly, saddle-shaped tuberculate, constricted in prozona. Dark brown and paler brown in color. Antennae dark brownish with white spots at base. Tegmina semitransparent; basal half dirty light brown 
with a diffuse spot at margin, apical margin shining with or without brown speckles. Wings rosy red at base, apex with distinct brown speckles, dark band lunar-shaped.
Inner surface of hind femur yellow with black speckles, outer surface paler brown with black spots dorsally with 2-3 black spots. Hind tibia pale in color.
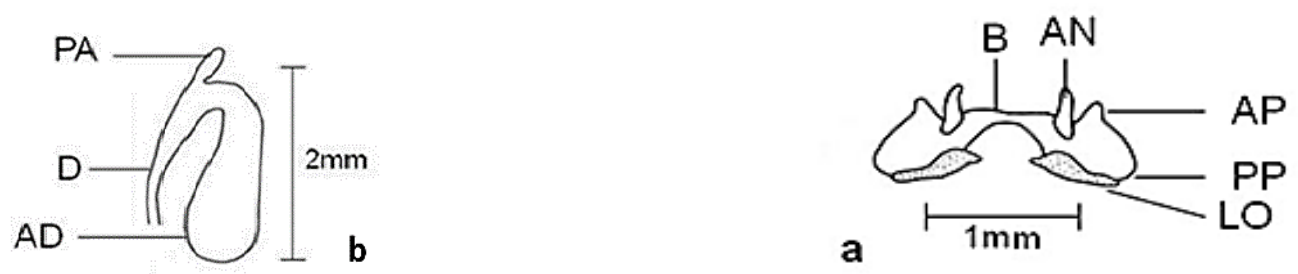

Figure 1. Acrotylus humbertians a) Epiphallus. b) Spermatheca

\section{Morphometry (length in $\mathbf{m m}$ )}

Female: Body 18-21, Antennae 7, Pronotum 4, Tegmina 19-21, hind Femur 9-10, hind tibia 10-11.

Male: Body 15-17, Antennae 5-7, Pronotum 3, Tegmina 15-17, hind Femur 8, hind tibia 9.

Epiphallus: Epiphallus bridge shaped, bridge narrow, straight connected with lateral plates. Anterior projections small and having rounded apices; lateral plates somewhat expanded posteriorly. Ancorae incurved with rounded acute apices, pointed narrow at the base. Lophi straight, with large apical lobes, posterior projection knob like and with rounded apices. Besides the lateral plates rounded small oval sclerites.

Spermatheca: Ovipositor with curved valves, ventral valve with lateral projection. The spermatheca with preapical diverticulum short, thin, oval slightly lateral upwarded with obtuse rounded apex. Apical diverticulum elongated, sac like with broad median process, smoothly rounded at base (Figure 2).
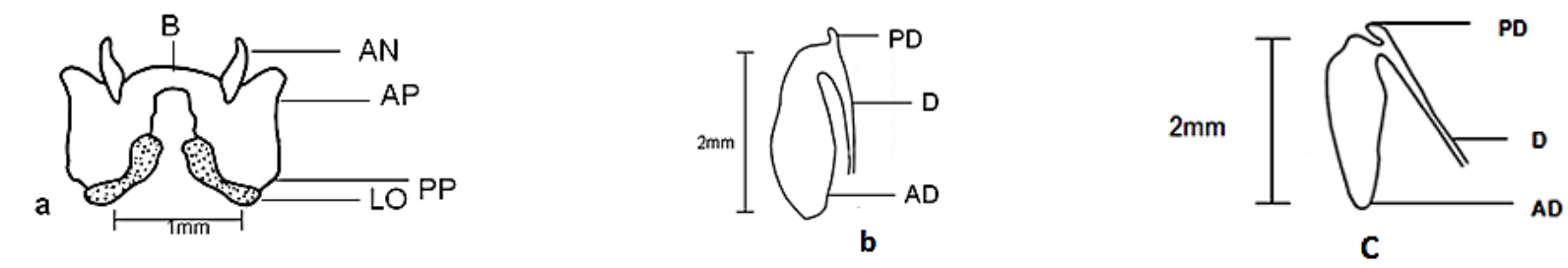

Figure 2. Acrotylus insubricus insubricus a) Epiphallus b) Spermatheca c) Spermatheca

\section{iii) A. patruelis (Herrich-Schaffer)}

Diagnostic characters: Medium size. Antennae filiform longer than head and pronotum together with 25 segments, longer than head and pronotum together. Head conical, shorter than pronotum. Fastigium of vertex triangular, lateral carinulae raised. Fastigial foveolae triangular; frontal ridge sulcate, constricted above the antennae, widened at clypeus. Usually dusty brown in color. Antennae dark brownish with white spots at base. Tegmina semitransparent with incomplete light band at base, apex transparent with brownish speckles. Wings hyaline, transparent, base light rose in color, dark band short, narrow and smoky, not reaching anteriorly to anal vein.

\section{Morphometry (length in $\mathbf{m m}$ )}

Female: Body17-21, Antennae 6- 7, Pronotum 4, Tegmina 20-21, hind Femur 10-11, hind tibia 10.

Spermatheca: Ovipositor small, valves with curved apices. The spermatheca with pre-apical diverticulum moderate, laterally up warded with rounded apex. Apical diverticulum fairly cylindrical, somewhat narrow and oval rounded at base.

\section{iv) A. longipes longipes (Charpentier)}

Diagnostic characters: Small to medium size, hairy rugose, Antennae filiform longer than head and pronotum together with 23 segments. Head shorter about little raised than pronotum. Fastigium of vertex angular, concave with lateral carinulae. Fastigial foveolae present 
almost triangular in shape, frons vertical. Pronotum short, tuberculate, constricted in prozona; median carina visible, distinct, lateral carinae irregular; tuberculate. Tegmina and wings well developed frontal and middle legs shorter than hind legs. Hind femur slender. Hind tibia with 10 inner and 9 outer black tipped sharp spines. They are usually paler brown and dirty brown in color. Antennae dark brownish with white spots at base. Pronotum short but with brownish speckles. Tegmina semitransparent, basal half light brown with irregular light spots on margin. Wings usually hyaline, base shining yellow without dark bands. Apex 2-3 small dark speckles. Hind femur with two black bands in inner side knee blackish on the inner aspect. Hind tibia pale.

\section{Morphometry (length in $\mathbf{m m}$ )}

Female: Body 18, Antennae 6, Pronotum 3, Tegmina 18, hind Femur 9, hind tibia 8.

Epiphallus: The epiphallus is bridge shaped, bridge narrow to moderately wide, with straight sheath. Anterior projections small with antero-median processes; subacute at apex. Lateral plates expanded posteriorly. Ancorae moderate, straight obtuse rounded at apex, little furrow at base. Lophi diverging sharply from the lateral plates, upcurved and anteriorly directed; having broad apical lobes ending in small, rounded terminal process. Beside the lateral plates circular oval sclerites.

Spermatheca: Ovipositor short with curved valves conical and straight, lower valve with angular lateral projection. The spermatheca with pre-apical diverticulum large laterally upwarded with rounded acute apices at apex. Apical diverticulum sac-like, elongated and smoothly rounded at base (Figure 3).

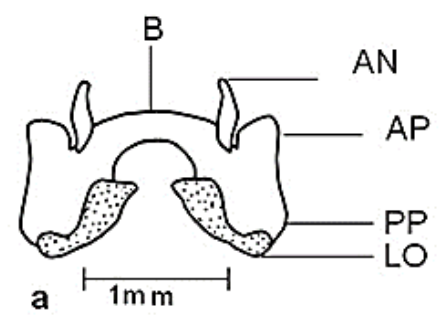

Figure 3. Acrotylus longipes longipes a) Epiphallus b) Spermatheca

\section{v) A. longipes subfasciatus}

Diagnostic characters: Of small to medium size, hairy, Antennae filiform with 23-25 segments, longer than head and pronotum together. Head conical shorter than pronotum. Fastigium of vertex triangular with raised lateral carinulae. Fastigial foveolae distinct, irregular; frons vertical, lateral carinulae slightly diverged towards the clypeus. Paler brown in color. Antennae dark brownish with white spots at base. Pronotum smaller but with white brownish speckles. Tegmina semitransparent, basal half light brown, with a light brown spot at margin, apical margin without half brown speckles. Wings hyaline, yellowish at base, dark band short lunar type. Hind femur has inner light brown incomplete band along the ventro-external carina; but shining pale above the ventro-external carina, dorsal edge with 2 brown spots. Hind tibia pale.

\section{Morphometry (length in $\mathbf{m m}$ )}

Female: Body 20-22, Antennae 6-8, Pronotum 4, Tegmina 17-22, hind Femur 9-12, hind tibia 9-10.

Male: Body 15-18, Antennae 6-7, Pronotum3, Tegmina 16-17, hind Femur 9-10, hind tibia 8-9.
Epiphallus: Epiphallus bridge shaped, bridge narrow, straight connected with lateral plates. Anterior projections small and having rounded apices; lateral plates somewhat expanded posteriorly. Ancorae incurved with rounded acute apices, pointed narrow at the base. Lophi straight, with large apical lobes, posterior projection knob like and with rounded apices. Besides the lateral plates rounded small oval sclerites.

Spermatheca: Ovipositor short and robust, valves Curved dorsal valves hook like, ventral valve with external lateral projection. The pre-apical diverticulum upward, slightly laterally placed; rounded at apex. Apical diverticulum moderate, sac like, smoothly rounded at base (Figure 4).

\section{DISCUSSION}

The spermatheca is an organ playing a key role in insect reproduction, allowing the storage of spermatozoa and making them available when it needed, at the same time performing an efficient use of spermatozoa during the fertilization process (Parker, 1970). Many researchers also investigated the role played by the secretion of the 
glands associated with male genitalia for Blattodea (Mullins and Keil, 1980), Orthoptera (Gwynne, 1988),
Lepidoptera (Boggs and Gilbert, 1979) and Coleoptera (Boucher and Huignard, 1987).
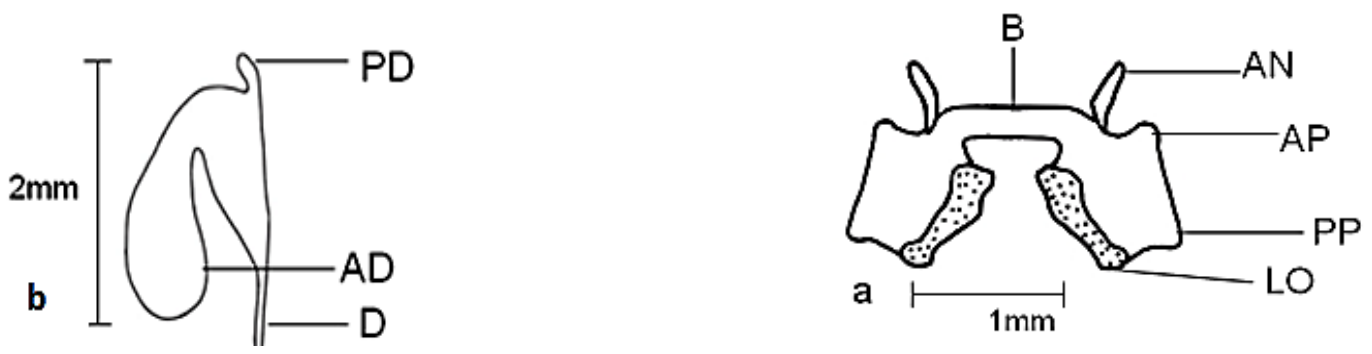

Figure 4. Acrotylus longipes subfasciatus a) Epiphallus b) Spermatheca

In Locusta migratoria L. (Orthoptera: Acrididae), substances produced by male accessory glands are transferred toward the spermatheca during mating process. As in the case of Acrotylus humbertians; epiphallus bridge-shaped, bridge somewhat broad and slightly curved outwardly. The distance between the tips of ancorae is measured about 1.6 millimeters; and later on the space between the lobate parts of lophi approximately was 0.8 millimeters; furthermore the length position of ancorae is measured about 1.0 millimeters. Whereas anterior process is well marked and extended upwardly, with obtuse sub-acute apices. Ancorae large not so narrower but straight, slightly incurved and with acute apices. Eventually lateral plates expanded greatly towards posterior portion. Lophi slightly wide, elongated rectangular, divided into inner lobate part and outer narrow portion; posterior projections prominent almost rounded and be set with smaller spinules on the dorsal surface. Besides the lateral plates oval, sclerites may be seen smoothly. After this the Acrotylus insubricus insubricus have bridge-shaped epiphallus, bridge narrow but slightly thin. The extent range between the tips of ancorae is measured about 2.8 millimeters; furthermore the interval cleft between the lobat parts of lophi is measuring about 0.4 millimeters; later on the length position of ancorae approximately 1.2 millimeters. Anterior projections protruding outwardly with sub-acute rounded apices; posterior portion of the lateral plates strongly expanded and extending well beyond with shallow deep process. Ancorae almost stout, long laterally placed; fairly convex at apex, and being thick at lower middle portion. Lophi elongated, cylindrical, having furrow at middle part, about denticulate at apex; anterior lobate portion wider than posterior lobate part; having rounded terminal processes.
Dorsally lophi be set with smaller enormous sclerites. Besides the lateral plates oval sclerites. The spermatheca of Acrotylus patruelis possesses a long tube and opens on the dorsal wall of the genital cavity, opposite to the genital opening. Pre-apical diverticulum moderate, laterally up warded with rounded apex. Apical diverticulum fairly cylindrical, little narrow and oval rounded at base. Although Acrotylus longipes longipes comprised varied epiphallus; bridge-shaped, bridge narrow to moderately wide, with slightly convex sheath dorsally. The sperm are released from the spermatheca only when the eggs pass down the oviduct, so fertilization may occur just before the eggs are laid. Further, the shape of pouch or sac and 'spermathecal tubules' within the spermatheca vary among species and such characters may be noted for taxonomical study. The seminal receptacles function for the collection and storage of the sperm, while the spermathecal tube is responsible for the sperm transport.

\section{REFERENCES}

Ahmed, F.U., 1980. Survey of grasshoppers in arid and semi arid region of Pakistan. Final Rep. Pl-480 No.PK-ARS-20 (FG-Pa-21).

Ahmed, I., Gillott, C., 1981. The spermatheca of Melanoplus sanguinipes (Fabr.). 1. Morphology, histology, and histochemistry. International Journal of Invertebrate Reproduction 4, 281-295.

Baloch, N., 2000. Survey and Taxonomy of the grasshoppers belonging to the family Acrididae (Orthoptera) of the Punjab. University of Sindh, Jamshoro, Pakistan, pp. 1-197.

Bei-Beinko, G.Y., Mishchenko, L.L., 1951. Locust and Grasshoppers of USSR and adjacent countries. 1 \& 2 Monson. Jerusalem. 691 pp.

Boggs, C.L., Gilbert, L.E., 1979. Male contribution to egg production in butterflies: evidence for transfer of nutrients at mating. Science 206, 83-84.

Boucher, L., Huignard, J., 1987. Transfer of male 
secretions from the spermatophore to the female insect in Caryedon serratus (OL.): Analysis of the possible trophic role of these secretions. Journal of Insect Physiology 33, 949-957.

Chiang, R.G., 2010. A newly discovered sperm transport system in the female of Lygaeidae bugs. Physiological Entomology 35, 87-92.

Dirsh, V.M., 1957. The spermatheca as a taxonomic character in Acridoidea (Orthoptera), Proceedings of the Royal Entomological Society of London. Series A, General Entomology. Wiley Online Library, pp. 107-114.

Dirsh, V.M., 1975. Classification of the acridomorphoid insects. Classey Ltd., Farringdon VIII. pp. 171.

Gschwentner, R., Tadler, A., 2000. Functional anatomy of the spermatheca and its duct in the seed bug Lygaeus simulans (Heteroptera: Lygaeidae). European Journal of Entomology 97, 305-312.

Gupta, P.D., 1948. On the structure, development and homology of the female reproductive organs in ortho pteroid insects. Indian Journal of Entomology $10,75-123$.

Gwynne, D.T., 1988. Courtship feeding and the fitness of female katydids (Orthoptera: Tettigoniidae). Evolution 42, 545-555.

Kevan, D.K.M., Akbar, S.S., Chang, Y.-C., 1969. The concealed copulatory structures of the Pyrgomorphidae (Orth. Acridoidea): Part I. General introduction. EOS, 165-216.

Kharibam, M., Shafee, S.A., Usmani, M.K., 1982. Taxonomic significance of spermatheca in some Indian grasshoppers.(Orthoptera: Acrididae). Journal of the Bombay Natural History Society 79, 331-335.

Kirby, W.F., 1914. The fauna of British India including Ceylon and Burma. Orthoptera (Acrididae). London Taylor and Francis. pp. 276.

Mullins, D.E., Keil, C.B., 1980. Paternal investment of urates in cockroaches. Nature 283, 567-569.

Pal, S.G., Ghosh, D., 1982. Electron microscopic study of the spermatheca of Gesonula punctifrons (Acrididae: Orthoptera). Proceedings of the Indian Academy of Sciences Animal Sciences 91, 99-112.

Parker, G.A., 1970. Sperm competition and its evolutionary consequences in the insects. Biological Reviews 45, 525-567.
Qadri, M.A.H., 1940. On the development of the genitalia and their ducts of orthopteroid insects. The Transactions of the Royal Entomological Society of London 90, 121-175.

Ritchie, J.M., 1981. A taxonomic revision of the genus Oedaleus Fieber (Orthoptera Acrididae). Bulletin of the British Museum (Natural History) 42, 83-183.

Ritchie, J.M., 1982. A taxonomic revision of the genus Gastrimargus Saussure (Orthoptera :Acrididae) Bulletin of the British Museum (Natural History) 44, 239-329.

Slifer, E.H., 1939. The internal genitalia of female Acridinae, Oedipodinae and Pauliniinae (Orthoptera, Acrididae). Journal of Morphology 65, 437-469.

Slifer, E.H., 1940a. The internal genitalia of female Thrinchinae, Batrachotetriginae, Pamphaginae and Pyrgomorphinae (Orthoptera, Acrididae). Journal of Morphology 66, 175-195.

Slifer, E.H., 1940b. The internal genitalia of female Ommexechinae and Cyrtacanthacridinae (Orthoptera: Acrididae). Journal of Morphology 67, 199-239.

Slifer, E.H., 1940c. Variations in the spermatheca of two species of grasshoppers (Orthoptera-Acrididae). Entomological News 51, 1-3.

Slifer, E.H., 1943a. The internal genitalia of some previously unstudied species of female Acrididae (Orthoptera). Journal of Morphology 72, 225-237.

Slifer, E.H., 1943b. The internal genitalia of female Tetrigidae, Eumastacidae and Proscopiidae (Orthoptera). Journal of Morphology 73, 89-110.

Tokhai, S., 1997. Survey and taxanomy of Orthoptera of Zhob Division (Balochistan) and adjoining areas. University of Sindh, Jamshoro, Pakistan, pp. 1-201.

Uvarov, B.P., 1966. Grasshoppers and Locusts. A hand book of general acridology Cambridge University Press (London) 1: Xii + 481, pp. 1-201.

Vickery, V.R., Kevan, D.K.M., 1983. A monograph of the orthopteroid insects of Canada and adjacent regions. Mem. Lyman ent. Mus. Res. Lab. 13:(I) ixxii + 1-679; (II) i-iv + 680-1462.

Wagan, M.S., Solangi, S.M., 1990. Distribution and incidence of grasshoppers (acrididae) of Sind. Biol. San. Veg. Plagas. (Fuera deserie) 20,125-129. 